Galina V. Verkhova ${ }^{1}$, Sergey V. Akimov', Maxim M. Kotelnikov3 $\quad$ DOI: 10.25045/jpit.v10.i2.04 Department of Automation of Communication Enterprises, The Bonch-Bruevich Saint-Petersburg State University of Telecommunications, St. Petersburg, Russia ${ }^{1}$ galina500@inbox.ru, ${ }^{2}$ akimov-sv@yandex.ru, ${ }^{3}$ max.kat.ru@mail.ru

\title{
GENERALIZED MODEL OF THE ADDITIONAL REALITY SYSTEM
}
Received: 21.12.2018
Revised: 27.02.2019
Accepted: 10.03.2019

The article presents a generalized model of augmented reality system. It is shown how this model can be used to create modular systems that support the technology of augmented reality. Unification methods in the field of augmented and mixed reality are proposed. The role of complemented and mixed reality technology in the framework of the unified cyber environment of the information society is demonstrated.

Keywords: augmented reality, augmented reality system, a generalized model of augmented reality, a mixed reality, a single cyber environment of the information society, information and analytical layer of mixed reality.

\section{Introduction}

The technology of augmented reality is increasingly used in the modern world [1-4]. Complemented and mixed reality will become an integral part of the emerging cyber environment of the postindustrial society and technologies of "Industry 4.0" in the near future [5-6], providing a visual way of monitoring and managing the object through digital counterparts. The concept of augmented reality is presented in figure 1.

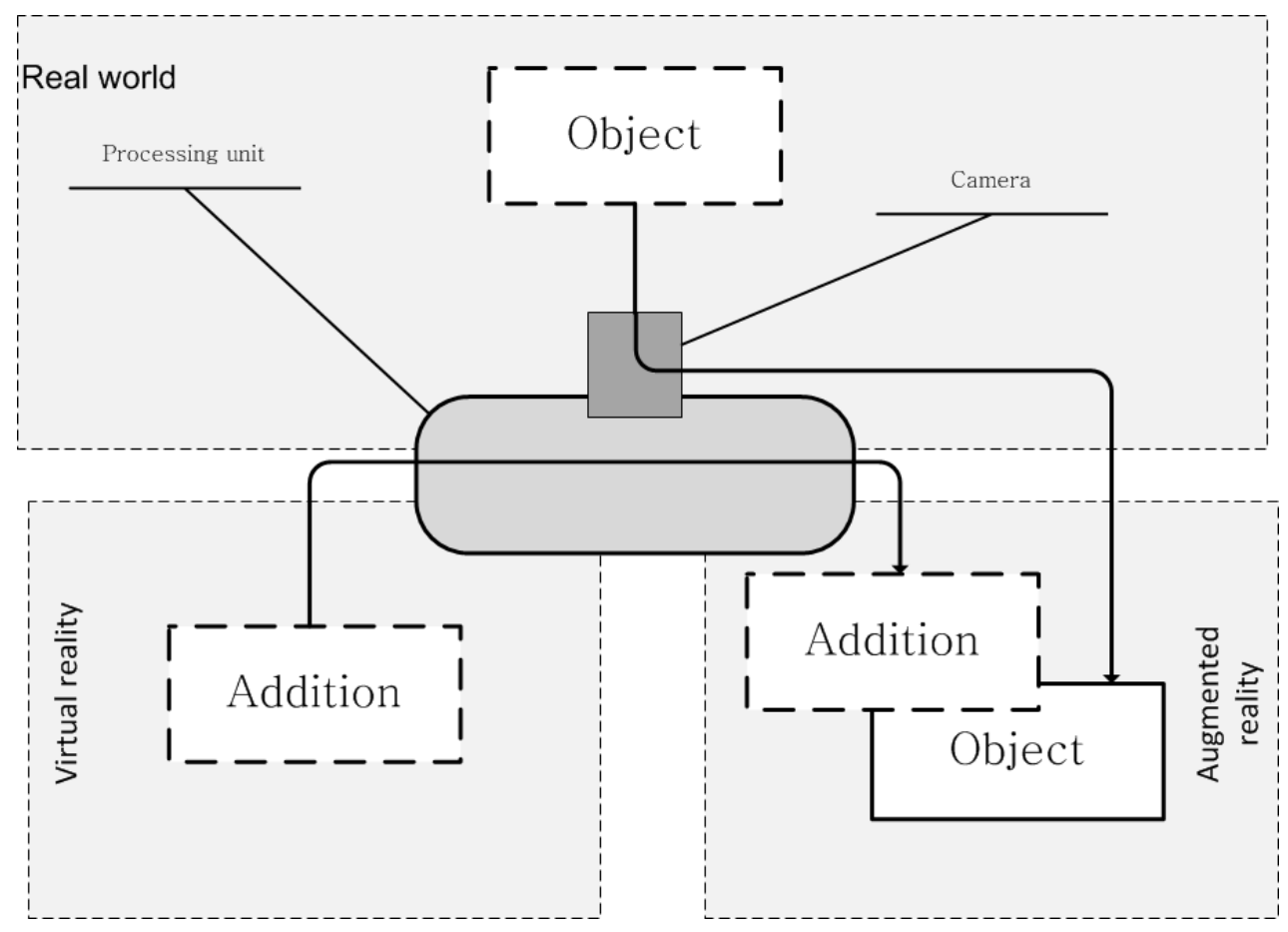

Figure 1. The conceptual scheme of augmented reality

Figure 2 represents the medial matrix (medial continuum), which reflect the position of the augmented reality relative to the real and virtual worlds, as well as their modifications [7-12]. At the origin is reality, the abscissa is the axis of virtuality, and the ordinate axis is the medial axis. The continuum, located along the axis of virtuality, includes augmented reality, as well as augmented virtuality. 


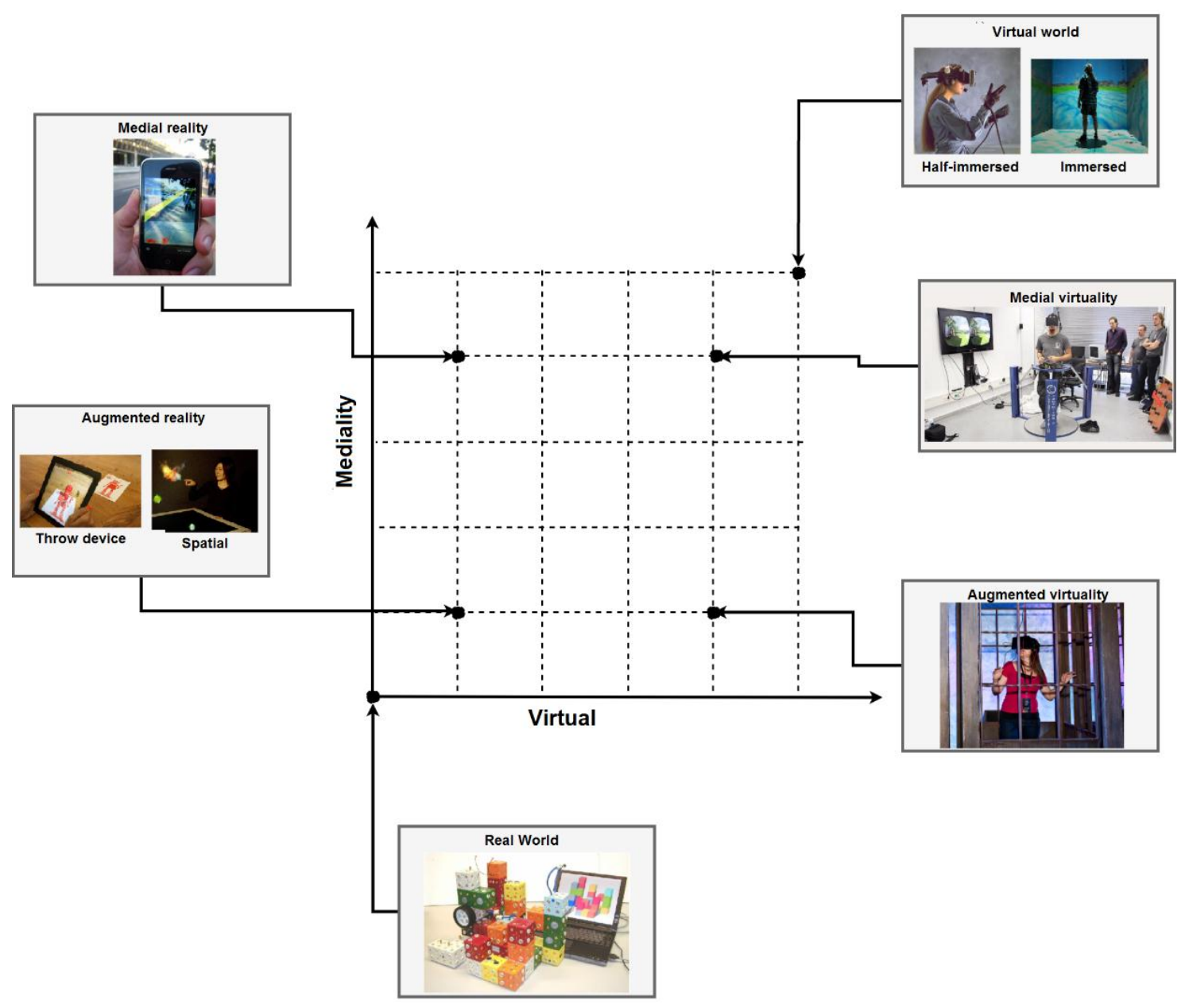

Figure 2. The Media Matrix

Taxonomy also includes modifications of reality, virtuality, and their modifications. Modification means moving up the medial axis. When moving up this axis, we can find mediated reality, mediated virtuality, or any combination of them. If you move up and to the right, you can find virtual worlds that react to heavily modified versions of reality.

At the moment there are many libraries and specialized software that allow you to create and reproduce objects of augmented reality. All software and libraries are based on complex mathematical calculations, but in most cases, the algorithm for their implementation is universal. This enables to create a generalized model of the augmented reality architecture built on a modular basis, and provide the ability to perform the assembly of the system from the ready-made modules from different manufacturers in such a way that the resulting system maximally satisfies the conditions of the task.

\section{The architecture of the generalized model of additional reality}

Figure 3 presents the architecture of the generalized model of augmented reality system, which can be represented by the expression

$$
A R=\langle V C, T R K, P S, V R S, V R D B, M I U, A R O p, O U T>,
$$

that represents main component of an augmented reality system. 


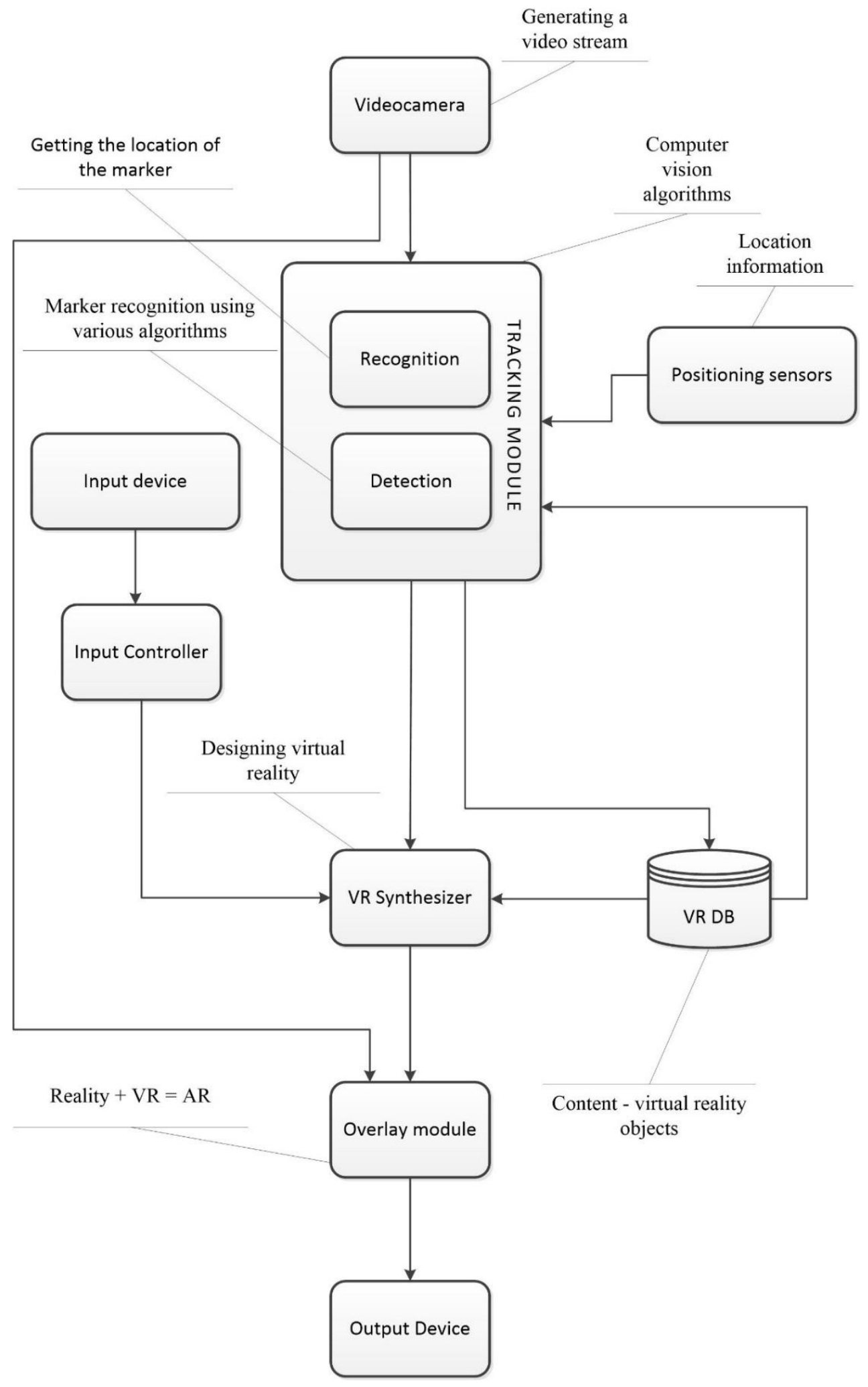

Figure 3. The architecture of the generalized model of the augmented reality system

Below is the list of the components of expression (1):

$V C$ - video camera;

$T R K$ - tracking module;

$P S$ - positioning sensors;

$V R S$ - virtual reality synthesizer; 
$V R D B$ - database of virtual reality objects;

$M I U$ - input device;

$A R O p$ - system of superimposing virtual reality to "physical" reality

OUT - output device.

With the help of a video camera (VC) or a set of video cameras, the system receives information about the world of physical reality, which will be supplemented with virtual reality objects, that are stored in the corresponding database (VRDB). In addition to video cameras, other types of sensors can be used, such as rangefinders and laser scanning systems of the object, which together with the positioning sensor system will allow more accurate addition of physical objects by virtual ones. The object is tracked in the tracking module.

Virtual objects of augmented reality are formed in the virtual reality synthesizer (VRS). At the input of the virtual reality synthesizer comes a digital image of the complemented physical object containing its coordinates calculated in the tracking module, as well as a virtual reality object that will be superimposed on the image of the physical object. In addition, the virtual reality synthesizer receives information from the input device (MIU), through which the user can manage virtual objects.

The overlay module (AROp) receives information from the video camera containing a digital image of physical reality (Reality), and virtual objects (VR), which will be supplemented by physical reality:

$$
A R=\text { Reality } \cup V R \text {. }
$$

After the overlay module, the information goes to the output device, in which the mobile device (smartphone, tablet), the virtual reality helmet, or enlarged reality glasses can perform. If you use the augmented reality glasses, you do not need to translate the image of the physical object. The user's retina transmits only virtual objects that supplement (augmentation) the objects of the physical world (2), which he perceives naturally.

Information on the input and output information flows of the modules of the augmented reality system is presented in table 1 .

Table 1

Input and output flows of modules

\begin{tabular}{|c|c|c|}
\hline Module & Input & Output \\
\hline VC (video camera) & Real object & Digital video stream \\
\hline TRK (tracking module) & $\begin{array}{l}\text { Digital video stream, information } \\
\text { from the database of virtual objects } \\
\text { and from positioning sensors }\end{array}$ & $\begin{array}{l}\text { Information about the } \\
\text { coordinates of the } \\
\text { supplemented object }\end{array}$ \\
\hline $\begin{array}{l}\text { VRS (virtual reality } \\
\text { synthesizer) }\end{array}$ & $\begin{array}{l}\text { Information about coordinates of the } \\
\text { supplemented object, virtual object } \\
\text { and commands coming from the } \\
\text { input device }\end{array}$ & Virtual addition \\
\hline AROp (overlay module) & $\begin{array}{l}\text { Digital video stream and virtual } \\
\text { complement }\end{array}$ & Augmented Reality \\
\hline PS (positioning sensors) & $\begin{array}{l}\text { Information needed to position the } \\
\text { Augmented Reality System }\end{array}$ & $\begin{array}{l}\text { Coordinates on the } \\
\text { position of the Augmented } \\
\text { Reality System }\end{array}$ \\
\hline
\end{tabular}

The proposed model is universal and can be used both in marker and nonmarked Augmented Reality technology, implemented with the help of smartphones and tablets, virtual reality helmets and enlarged reality glasses. In addition, it can be generalized to a system of mixed reality, which provides a deeper degree of integration of virtual reality into physical reality [13-15]. 
A generalized model of augmented reality (1) is created using the methodology of complex models [5-6], and can be viewed as part of a single environment of cross-cutting multi-dimensional modeling, on the basis of which a single cyber environment of the information society is built.

The complex model is designed to unite many mathematical and computer models representing various aspects of objects into a single unit.

$$
C X M=\left\langle A^{o b}, M^{o b+}, R^{C X M}>\right.
$$

where $A^{o b}$ are the aspects of the object under consideration, and the system aspects of the class of objects, $M^{o b+}$ are formalisms for representing aspects of the object and the system aspects of the class of objects, $R^{C X M}$ are links between technical and economic characteristics, technical and economic requirements and $M^{o b+}$.

For the purposes of computer modeling, a complex model (3) can be expressed in the following formula:

$$
C X M=\left\langle P^{(1)}, I, E, I^{E}, R, P^{(2)}, \text { Eval, } \text { Valid }>\right.
$$

where $P^{(1)}$ are primary parameters of the object, $E$ is information about the components (subsystems) that make up the object, $I$ is information about the interfaces of the modeled object, $I^{E}$ is information about the interfaces of the components (subsystems), $R$ is switching space, $P^{(2)}$ are secondary parameters of the object, Eval are rules for calculating the secondary parameters of the object, Valid are object validation rules.

Complex models (3-4) do not replace other types of models (mathematical, imitative, statistical), but are a kind of a superstructure over them. They are the link that unites the other models into a single whole. Thus, in the theory of complex models, mechanisms are developed that ensure following:

- consolidation of information models describing various aspects of the object in a single system;

- links between information models and predictive models (mathematical physics, imitative, statistical);

- manipulation of information models without reference to predictive models (finding objects that meet certain requirements, determining compatibility between objects, integrating objects), including multi-criteria and intelligent search, taking into account the compatibility of objects.

The presented model can be used as a basis for developments in the field of standardization and unification of augmented reality systems in order to ensure compatibility of software and hardware components from different manufacturers. Solving the problem of compatibility will positively affect the process of introducing the technology of augmented reality into all spheres of human activity.

\section{Systems of additional and mixed reality in a single cyber environment of information society}

Currently there is an urgent need for the development of cyberspace, which is necessary to provide comprehensive security, economic development, strengthen international ties, improve the well-being of citizens of the post-industrial society. The cyber environment under notion consists of four layers (figure 4).

The sensor layer provides collection and initial processing of information on monitoring and control objects. Sensors possess different physical quantities and audiovisual surveillance modes, including high-definition 3D video. Sensors and surveillance equipment can be both stationary and installed on manned and unmanned aerial vehicles, automatic probes, artificial earth satellites, underwater and surface vessels. In addition, smartphones, action cameras, GPS and GLONASSnavigators, autoregistrators and other online and offline devices can act as such tools. 


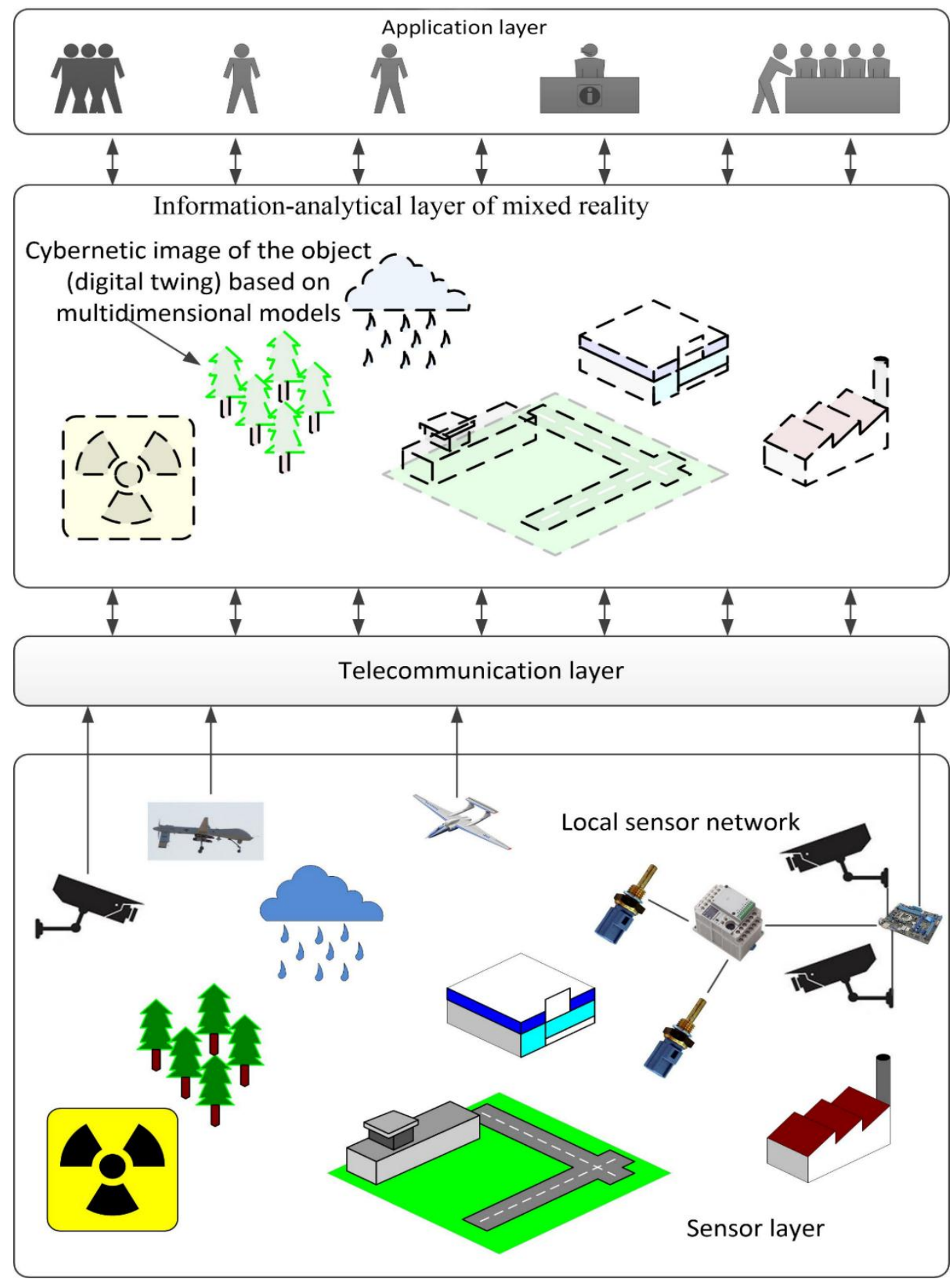

Figure 4. The architecture of the unified cyber environment of the information society

The telecommunication layer provides the transmission of information flows in the cyberspace, which is a distributed system. This layer maximizes the existing infrastructure, the capacity of the Internet and departmental networks.

In the information and analytical layer of mixed reality, based on multidimensional models, information is being integrated on monitoring objects received from the sensory layer, as well as from departmental, corporate and regional monitoring and information systems. An augmented reality environment is formed, as well as virtual images of monitoring objects (digital counterparts), on the basis of which a mixed reality is created, which ensures the integration of real-world objects into a virtual environment. 
This layer is based on a family of multidimensional models of bio- and technosphere objects (man-made objects, systems of provision and safety of vital activity), as well as historical and cultural heritage. These models derive boundary conditions from the sensory layer, and thus can be considered as cybernetic images of these objects.

The application layer provides various areas of activity and monitoring. Unified situation centers of federal, regional and municipal levels are created, as well as a center for cyber environment management. A cybernetic scientific and educational environment is being developed, deeply integrated with the electronic resources of libraries, museums, various types of educational institutions, and contains comprehensive information on personalities, organizations, ongoing and completed projects, and intellectual property objects.

\section{Conclusion}

The proposed generalized model of the augmented reality system, created on the basis of the methodology of complex models, provides identification of functional blocks and information flows between them, which together provide the solution of the task of supplementing physical reality with virtual objects. This model can be used as a basis for unification and standardization in the field of software and hardware for augmented reality systems, providing the creation of modular systems of augmented and mixed reality that are integrated from components from different manufacturers.

A generalized model of the augmented reality system can be used to create a single cyber environment for the information society. It can be used as the basis for an information-analytical layer of mixed reality, in which monitoring and management of technogenic objects are carried out through virtual images (digital counterparts).

\section{References}

1. Morey S., Tinnell J. Augmented Reality: Innovative Perspectives across Art, Industry, and Academia. Parlor Press, 2016, 368 p.

2. Papagiannis H. Augmented Human: How Technology Is Shaping the New Reality. O'Reilly Media, 2017, $156 \mathrm{p}$.

3. Kollatsch C., Schumann M., Klimant P., Lorenz M. Industrial Augmented Reality: Transferring a Numerical Control Connected Augmented Realty System from Marketing to Maintenance / 2017 IEEE International Symposium on Mixed and Augmented Reality (ISMAR-Adjunct), 2017, pp.39-41.

4. Albert A. The Augmented Library: An Approach for Improving Users Awareness in a Campus Library / 2017 IEEE International Symposium on Mixed and Augmented Reality (ISMARAdjunct), 2017, pp.15-19.

5. Verkhova G.V., Akimov S.V. Multi-aspect modeling system objects in CALS / Proceedings of 20th IEEE International Conference on Soft Computing and Measurements (SCM), Russia, St. Petersburg, 2017, pp.449-451, DOI: 10.1109/SCM.2017.7970614.

6. Akimov S.V., Verkhova G.V., Metkin N.P. Teoreticheskie osnovy CALS. SPb, izdatel'stvo SPbGUT im. prof. M.A. Bonch-Bruevicha, 2018, 263 p.

7. Shu J., Kosta S, Zheng R., Hui P. Talk2Me: A Framework for Device-to-Device Augmented Reality Social Network / The Proceedings of IEEE International Conference on Pervasive Computing and Communications (PerCom 2018), Athens, Greece, March 2018.

8. Fournier A., Gunawan A. S., et al. Common Illumination between Real and Computer Generated Scenes // Proceedings of Graphics Interface '93: Front Hatter, 1993, pp.254-262.

9. Benderson Benjamin B. Audio Augmented Reality: A Prototype Automated Tour Guide Archived 1 July 2002 at the Wayback Machine / Bell Communications Research, ACM Human Computer in Computing Systems Conference, pp. 210-211. 
10. Milgram P., Kishino A. F. Taxonomy of Mixed Reality Visual Displays // IEICE Transactions on Information and Systems, 1994, pp.1321-1329.

11. Patton Debbie, Marusich Laura. Simulated network effects on tactical operations on decision making / 2015 IEEE International Multi-Disciplinary Conference on Cognitive Methods in Situation Awareness and Decision, pp.145-150.

12. Leão M., Lima J.P., Teichrieb V., Albuquerqu E.S., Kelner J. Altered reality: Augmenting and diminishing reality in real time / 2011 IEEE Virtual Reality Conference, 2012, pp.219-220.

13. Verkhova G.V., Akimov S.V., Gusev, A.N. Information environment for the training of highly qualified personnel in the system of continuous education / Proceedings of 2017 IEEE 6th Forum Strategic Partnership of Universities and Enterprises of Hi-Tech Branches (Science. Education. Innovations), SPUE 2017, pp.77-80. DOI: 10.1109/IV Forum, 2017.8246056.

14. Verkhova G.V., Akimov S.V. Electronic educational complex for training specialists in the field of technical systems management / Proceedings of 2017 IEEE 2nd International Conference on Control in Technical Systems (CTS 2017), pp.26-29. DOI: 10.1109/CTSYS.2017.8109479.

15. Kollatsch C., Schumann M., Klimant P., Lorenz M. Industrial Augmented Reality: Transferring a Numerical Control Connected Augmented Realty System from Marketing to Maintenance / IEEE International Symposium on Mixed and Augmented Reality (ISMARAdjunct), 2017, pp.39-41.

\section{UOT 004.946}

\section{Verxova Qalina V. ${ }^{1}$, Akimov Sergey V. ${ }^{2}$, Kotelnikov Maksim M. ${ }^{3}$}

M. A. Bonç-Brueviç adına Sankt-Peterburq Dövlət Telekommunikasiya Universiteti, SanktPeterburq, Rusiya

${ }^{1}$ galina500@inbox.ru, ${ }^{2}$ akimov-sv@ yandex.ru, ${ }^{3}$ max.kat.ru@ mail.ru

\section{Olavə reallıq sisteminin ümumiləşdirilmiş modeli}

Olavə reallıq sisteminin ümumiləşdirilmiş modeli təqdim edilmişdir. Bu modelin əlavə reallıq texnologiyasını dəstəkləyən modulyar sistemlərinin yaradılması zamanı istifadə olunma üsulu göstərilmişdir. Olavə və qarışıq reallıq sahəsində unifikasiya yolları təklif edilmişdir. İnformasiya cəmiyyətinin vahid kibermühiti çərçivəsində əlavə və qarışıq reallıq texnologiyasının rolu nümayiş etdirilmişdir.

Açar sözlor: ১lavə reallıq, alavə reallıq sistemi, əlavə reallı̆̆ın ümumilaşdirilmiş modeli, qarışıq reallıq, informasiya camiyyatinin vahid kibermühiti, qarışıq reallı̆̆ın informasiya-analitik qatı.

\section{УДК 004.946}

Верхова Галина В. ${ }^{1}$, Акимов Сергей В. ${ }^{2}$, Котельников Максим М. ${ }^{3}$

Санкт-Петербургский государственный университет телекоммуникаций им. проф. М.А. Бонч-Бруевича

${ }^{1}$ galina500@inbox.ru, ${ }^{2}$ akimov-sv@yandex.ru, ${ }^{3}$ max.kat.ru@mail.ru

\section{Обобщенная модель системы дополненной реальности}

Представлена обобщенная модель системы дополненной реальности. Показано, каким образом данная модель может быть использована при создании модульных систем, поддерживающих технологию дополненной реальности. Предложены пути унификации в области дополненной и смешанной реальности. Продемонстрирована роль технологии дополненной и смешанной реальности в рамках единой киберсреды информационного общества.

Ключевые слова: дополненная реальность, система дополненной реальности, обобщенная модель дополненной реальности, смешанная реальность, единая киберсреда информационного общества, информациионно-аналитический слой смешанной реальности. 